\title{
ANALYSIS OF THE VOLUME AND COST OF IMPORT OF METOCLOPRAMIDE TABLETS IN THE REPUBLIC OF UZBEKISTAN
}

\author{
Yunusova Kholida Mannanovna ${ }^{1}$ \\ ${ }^{1}$ Professor, \\ Department of Industrial Technology of \\ Medicines, \\ Tashkent Pharmaceutical Institute, \\ Tashkent, Uzbekistan
}

\author{
Samedinova Dilnoza Nuriddin qizi ${ }^{2}$ \\ ${ }^{2} \mathrm{PhD}$ Student, \\ Department of Industrial Technology of \\ Medicines, \\ Tashkent Pharmaceutical Institute, \\ Tashkent, Uzbekistan,
}

\begin{abstract}
We conducted an analysis of the volume and cost of the import of Metoclopramid tablets in the Republic of Uzbekistan with the assistance of the State Register of Medicines, Medical Supplies and Medical Equipment authorized for Medical Practice in the Republic of Uzbekistan in 2016-2020 and with the program «Drug Audit» including database information from 2016 to 2020. The results will serve as the basis for our further research on the development of production in the Republic of Uzbekistan of the tablet form of Metoclopramide.
\end{abstract}

KEY WORDS: prokinetics, Functional gastrointestinal disorders (FGDs), metoclopramide, antiemetic drugs.

\section{INTRODUCTION}

According to the decree of the President of the Republic of Uzbekistan «On additional measures to deepen reforms in the pharmaceutical industry of the Republic of Uzbekistan», in recent years, comprehensive measures have been implemented to improve the system of drug circulation, favorable conditions have been created for the development of the domestic pharmaceutical industry. At the same time, the domestic pharmaceutical industry does not sufficiently meet the needs of the population and medical institutions with pharmaceutical products $[1$, 3-5].

In order to further improve the provision of the population with high-quality, efficient and safe pharmaceutical products, expand production volumes, increase the scientific, technical and export potential of domestic manufacturers, as well as attract foreign direct investment, a five-year analysis was performed with further plans to improve the identified situation [7-9].

The concept for the development of the pharmaceutical industry of the Republic of Uzbekistan in 2020 - 2024 provides for: expanding the range of pharmaceutical products produced taking into account advanced scientific experience and modern technologies, as well as the development of the pharmaceutical industry by stimulating the development and production of innovative pharmaceutical products, commissioning modern production facilities, and also modernization and strengthening of the material and technical base of existing industries; development of the domestic pharmaceutical industry by ensuring that organizations and enterprises comply with the requirements of standards harmonized with international requirements for the development and production of pharmaceutical products; attraction of investments and advanced technologies, including foreign pharmaceutical companies, to the creation of modern competitive production facilities for the production of pharmaceutical products; reducing imports of pharmaceutical products through modernization, increasing existing production capacities and mastering new types of pharmaceutical products, as well as by attracting investments; creation of modern educational, laboratory and research centers focused on the development of 
original drugs, as well as generic drugs (generics) based on the original drugs in demand [1, 12-13].

Functional disorders of the gastrointestinal tract (GIT) can be attributed to diseases of the $21 \mathrm{st}$ century. Over the past decade, there has been a progressive increase in the number of patients with gastrointestinal symptoms that are not associated with organic lesions of the gastrointestinal tract [2, 15-17]

In recent years, a new group of medications has appeared - prokinetics, capable of correcting disorders of the motility of the digestive tract. These include a group of pharmacological drugs that, at different levels and with the help of various mechanisms, enhance the motor, primarily propulsive activity of the gastrointestinal tract [10].

Prokinetics are pharmacological drugs that, at different levels and using various mechanisms, change the propulsive activity of the gastrointestinal tract and accelerate the transit of a food bolus through it. Their potentiating effect on the motility of the stomach, duodenum, and, in some cases, the entire small and even colon is widely known. However, the usefulness of prescribing drugs of this group in gastroesophageal reflux disease is disputed by many leading gastroenterologists in the world [6].

An important indication for the use of prokinetics is vomiting of pregnant women or vomiting associated with chemotherapy of malignant diseases [11].
In the daily arsenal of a gastroenterologist, metoclopramide (cerucal) and domperidone (motilium, motoricum, perilium) are used. To answer the question of which group of drugs to give preference to for certain diseases, you need to know which parts of the digestive tract and how prokinetics act, and this depends on their mechanism of action [14-17].

Currently, only ondansetron (Osetron, Ontic, Onset) and metoclopramide (Metoclopramide, Metoclopramide-Darnitsa, Tomid) are available and used in clinical practice in Uzbekistan. The most widely used is Metoclopramide [7].

\section{MATERIALS AND METHODS}

In our research, we used the «DRUG AUDIT» program, data period 2016-2020, to determine the number of packages and costs associated with the supply of enterprises importing metoclopramide tablets, the volume of imports and the cost [7].

\section{RESULTS AND DISCUSSION}

When conducting marketing analysis, according to the «DRUG AUDIT» program, the import of Metoclopramide tablets in 2016, 2017, 2018, 2019 and 2020 was carried out mainly from the CIS countries (Belarus, Ukraine) enterprises such as BORISOVSKIY and DARNITSA, as well as from domestic enterprises in the Republic of Uzbekistan (GUFIK) (Table 1.2) [7].

Table 1

Information on the number of metoclopramide tablets in the Republic of Uzbekistan from the CIS countries for 2016-2020

\begin{tabular}{|c|c|c|c|c|}
\hline $\begin{array}{c}\text { Name of the } \\
\text { drug and } \\
\text { manufacturer / } \\
\text { year }\end{array}$ & $\begin{array}{c}\text { Metoclopramide } \\
\text { 10mg tab. No. 50 } \\
\text { (BORISOVSKIY, } \\
\text { Belarus) }\end{array}$ & $\begin{array}{c}\text { Metoclopramide } \\
\text { 250mg tab. No.10 } \\
\text { (BORISOVSKIY, } \\
\text { Belarus) }\end{array}$ & $\begin{array}{c}\text { Metoclopramide- } \\
\text { Darnitsa 0,01g tab. } \\
\text { No. 50 (DARNITSA, } \\
\text { Ukraine) }\end{array}$ & $\begin{array}{c}\text { Number of } \\
\text { packages, } \\
\text { pcs }\end{array}$ \\
\hline $\mathbf{2 0 1 6}$ & 76211 & 0 & 0 & 76211 \\
\hline $\mathbf{2 0 1 7}$ & 202358 & 0 & 0 & 202358 \\
\hline $\mathbf{2 0 1 8}$ & 182350 & 0 & 0 & 182350 \\
\hline $\mathbf{2 0 1 9}$ & 171620 & 20700 & 0 & 132320 \\
\hline $\mathbf{2 0 2 0}$ & 132071 & 0 & 0 & 132071 \\
\hline
\end{tabular}

Tablets of metoclopramide imported produced by enterprises of the CIS countries (Belarus and Ukraine) for five years amounted to 76211, 202358, 182350, 192320 and 132071, respectively. The analysis also provides data on the supply of metoclopramide tablets from foreign countries.
During the study period, the volume of imports of metoclopramide tablets from the CIS countries increased 2.6 times. 
Table 2

Information on the number of Metoclopramide tablet preparations in the Republic of Uzbekistan from domestic manufacturers for 2016-2020

\begin{tabular}{|c|c|c|}
\hline $\begin{array}{c}\text { Name of the drug and } \\
\text { manufacturer / year }\end{array}$ & $\begin{array}{c}\text { Tomid 10mg tab. No. 50 (GUFIK, } \\
\text { Uzbekistan) }\end{array}$ & Number of packages, pcs \\
\hline 2016 & 24500 & 24500 \\
\hline 2017 & 67689 & 0 \\
\hline 2018 & 0 & 0 \\
\hline 2019 & 0 & 0 \\
\hline 2020 & 0 & 089 \\
\hline
\end{tabular}

The data show that from 2016-2020, locally produced metoclopramide tablets were 24500,67689 , 0,0 and 0 packs, respectively. In general, we see that the production of metoclopramide tablets by local enterprises did not increase during the study period.

Figure 1

The volume of imports of Metoclopramide from the CIS countries and the production of Metoclopramide in the Republic of Uzbekistan from domestic countries

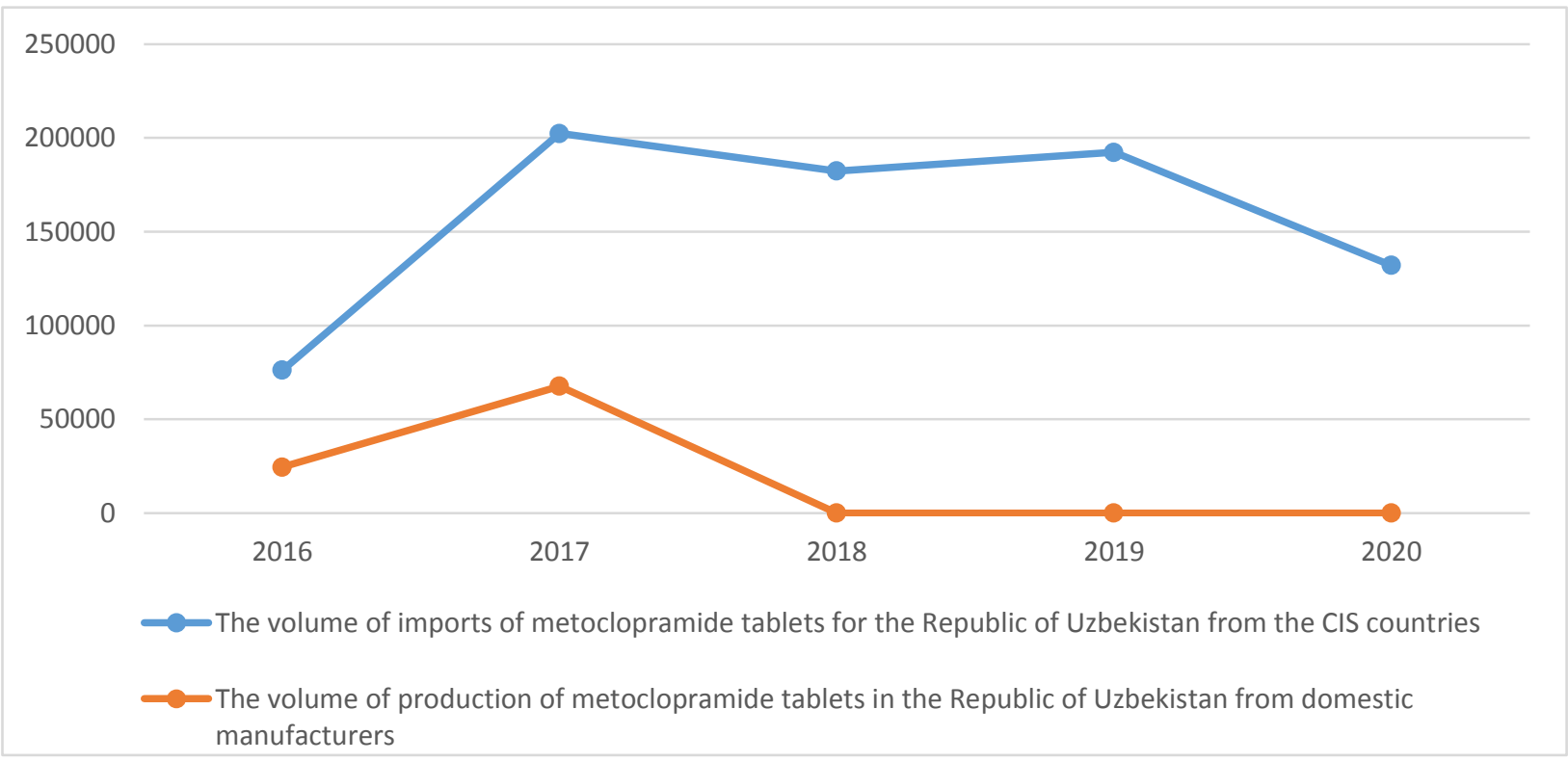

The results show that metoclopramide tablets produced by local factories for five years averaged $11 \%$ of the total, with the remaining $89 \%$ of drugs imported into the country for consumption through foreign exchange (Figure 1.2). 
Figure 2

Analysis of registration of metoclopramide tablets by country (for the period 2016-2020)

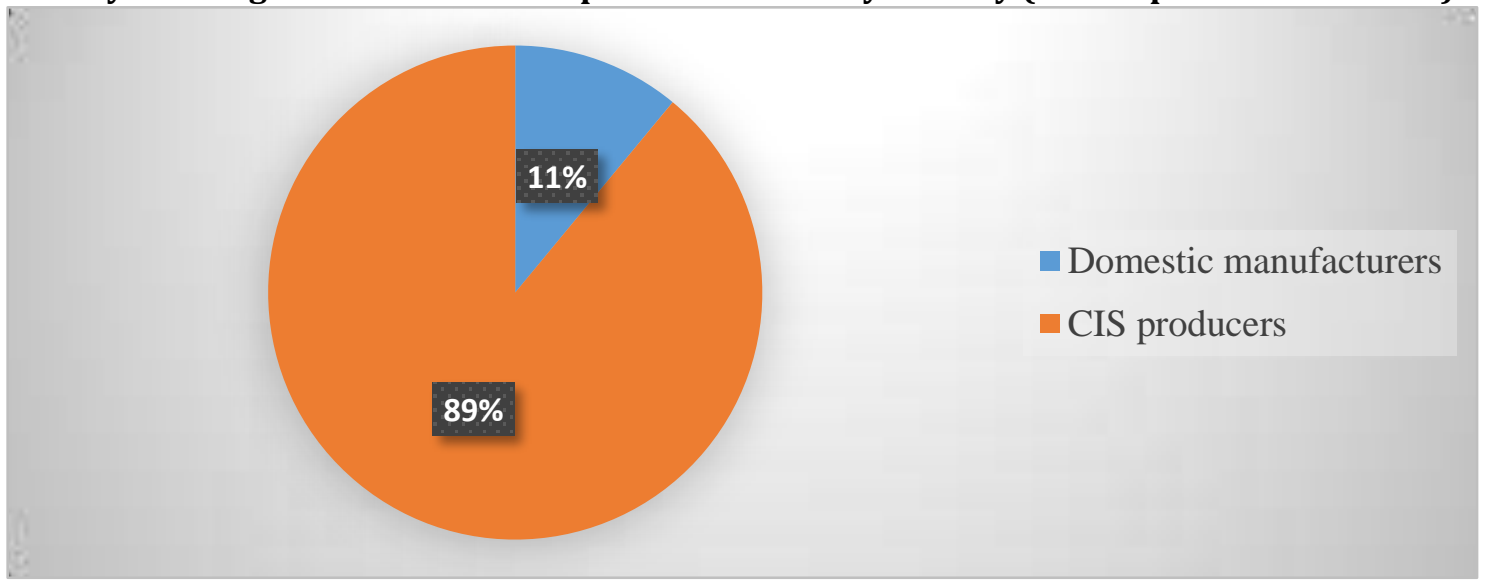

The determination of the costs associated with the supply of the antiemetic drug Metoclopramide for one package to the pharmaceutical market of the Republic of Uzbekistan can be found in Table 3 .

Table 3

The cost of metoclopramide tablets per package (\$) from the CIS and domestic enterprises in the Republic of Uzbekistan (2016-2020)

\begin{tabular}{|c|c|c|c|c|}
\hline $\begin{array}{c}\text { Name of the drug } \\
\text { and } \\
\text { manufacturer / } \\
\text { year }\end{array}$ & $\begin{array}{c}\text { Metoclopramide } \\
\text { 10mg tab. No. 50 } \\
\text { (BORISOVSKIY, } \\
\text { Belarus) }\end{array}$ & $\begin{array}{c}\text { Metoclopramide } \\
\text { 250mg tab. No.10 } \\
\text { (BORISOVSKIY, } \\
\text { Belarus) }\end{array}$ & $\begin{array}{c}\text { Metoclopramide- } \\
\text { Darnitsa 0,01g tab. } \\
\text { No. 50 (DARNITSA, } \\
\text { Ukraine) }\end{array}$ & $\begin{array}{c}\text { Tomid 10mg } \\
\text { tab. No. 50 } \\
\text { (GUFIK, } \\
\text { Uzbekistan) }\end{array}$ \\
\hline $\begin{array}{c}\text { Price for 2016 } \\
\text { (for 1 package, } \\
\text { \$) }\end{array}$ & 1.13 & 0 & 0 & 0.83 \\
\hline $\begin{array}{c}\text { Price for 2017 } \\
\text { (for 1 package, } \\
\text { \$) }\end{array}$ & 0.66 & 0 & 0 & 0.87 \\
\hline $\begin{array}{c}\text { Price for 2018 } \\
\text { (for 1 package, } \\
\text { \$) }\end{array}$ & 0.31 & 0 & & 0 \\
\hline $\begin{array}{c}\text { Price for 2019 } \\
\text { (for 1 package, } \\
\text { \$) }\end{array}$ & & & & \\
\hline $\begin{array}{c}\text { Price for 2020 } \\
\text { (for 1 package, } \\
\text { \$) }\end{array}$ & 0.33 & 0.07 & & 0 \\
\hline
\end{tabular}

The results of a marketing analysis of imports of produced Metoclopramide tablets from the CIS enterprises in 201686118 foreign currencies, in 2017133556 foreign currencies, in 201856529 foreign currencies, in 201958084 foreign currencies and 40627 foreign currencies in 2020. This shows that during the study period the price of metoclopramide tablets increased by 3.2 times (Table 4).

The prices of the metoclopramide tablets produced from domestic enterprises in 2016 amounted to 20335 foreign currencies, in 201758889 foreign currencies, in 2018-2020 the production of metoclopramide tablets was not carried out. As a 
EPRA International Journal of Multidisciplinary Research (IJMR) - Peer Reviewed Journal

Volume: 7 | Issue: 1 |January 2021|| Journal DOI: 10.36713/epra2013 || SJIF Impact Factor: 7.032 ||ISI Value: 1.188

result of the analysis, from 2016 to 2017, prices increased by 3 times (Table 5).

Table 4

Import prices of manufactured Metoclopramide tablets from CIS enterprises

\begin{tabular}{|c|c|c|c|c|}
\hline $\begin{array}{c}\text { Name of the } \\
\text { drug and } \\
\text { manufacturer / } \\
\text { year }\end{array}$ & $\begin{array}{c}\text { Metoclopramide } \\
\text { 10mg tab. No. 50 } \\
\text { (BORISOVSKIY, } \\
\text { Belarus) }\end{array}$ & $\begin{array}{c}\text { Metoclopramide } \\
\text { 250mg tab. N10 } \\
\text { (BORISOVSKIY, } \\
\text { Belarus) }\end{array}$ & $\begin{array}{c}\text { Metoclopramide- } \\
\text { Darnitsa 0,01g tab. } \\
\text { No. 50 } \\
\text { (DARNITSYA, } \\
\text { Ukraine) }\end{array}$ & $\begin{array}{c}\text { Total cost } \\
\text { (\$) }\end{array}$ \\
\hline 2016 & 86118 & 0 & 0 & 86118 \\
\hline 2017 & 133556 & 0 & 0 & 133556 \\
\hline 2018 & 56529 & 0 & 0 & 56529 \\
\hline 2019 & 56635 & 1449 & 0 & 58084 \\
\hline 2020 & 40627 & 0 & 0 & 40627 \\
\hline
\end{tabular}

Table 5

Prices of produced Metoclopramide tablets from domestic enterprises

\begin{tabular}{|c|c|c|}
\hline $\begin{array}{c}\text { Name of the drug and } \\
\text { manufacturer / year }\end{array}$ & $\begin{array}{c}\text { Tomid 10mg tab. No. 50 (GUFIK, } \\
\text { Uzbekistan) }\end{array}$ & Total cost (\$) \\
\hline 2016 & 24500 & 5358 \\
\hline 2017 & 67689 & 0 \\
\hline 2018 & 0 & 0 \\
\hline 2019 & 0 & 0 \\
\hline 2020 & 0 & 0 \\
\hline
\end{tabular}

A comparison of prices for 2016-2020 of supplies from the CIS countries and from domestic metoclopramide tablets in the Republic of Uzbekistan manufacturers can be seen in Figure 3.

Figure 3

Analysis of the cost of metoclopramide tablets in the Republic of Uzbekistan (2016-2020)

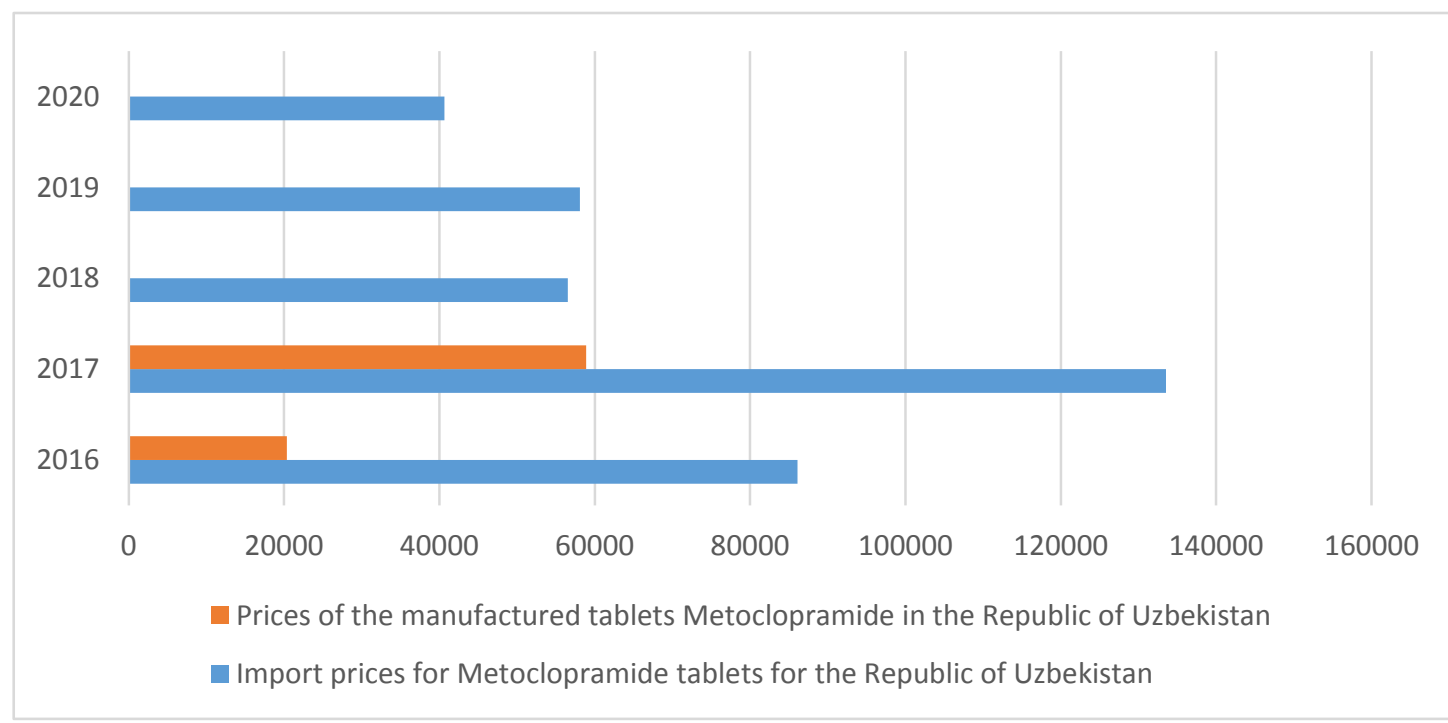




\section{CONCLUSION}

Thus, we have studied the supply of Metoclopramide tablets in the Republic of Uzbekistan. The result of the analysis of the above data shows that from the domestic manufacturers of the tablets metoclopramide is gradually increasing, but still, the percentage shows that the metoclopramide tablets are supplied mainly through imports, which is much higher in comparison with the volume of domestic manufacturers in the Republic of Uzbekistan. This indicates that in the future it is necessary to develop the technology for the production of metoclopramide tablets produced by domestic manufacturers. Given the fact that the population's demand for this drug remains high, this area today remains relevant for further research.

\section{REFERENCES}

1. Resolution of the President «On additional measures to deepen reforms in the pharmaceutical industry of the Republic of Uzbekistan». December 30, 2019. No. PP-4554.

2. Tkach, S. M. Prokinetics in the treatment of patients with functional disorders of the gastrointestinal tract. Health of Ukraine. Gastroenterology. Hepatology. Coloproctology: thematic issue. 2019. No. 4: 11.

3. S.E. Ravshanova, Yunusova Kh.M. Marketing analysis of non-narcotic analgesics in the pharmaceutical market of Uzbekistan. Materials of the XIV International Scientific and Practical Conference of Young Scientists and Students, dedicated to "Years of Rural Development, Tourism and Folk Crafts (20192021)". - 2019: 379.

4. S.E. Ravshanova, Yunusova Kh.M. Study of the range of combined non-narcotic analgesics. Materials of the XIV International Scientific and Practical Conference of Young Scientists and Students, dedicated to "Years of Rural Development, Tourism and Folk Crafts (2019-2021)". - 20019: 378.

5. Kh Yunusova, $S$ Ravshanova Analysis of combined products on the basis of metamizola natriy in the pharmaceutical market of the Republic of Uzbekistan. Pharmaceutical Bulletin of Uzbekistan.- 2019. No. 2: 25-30.

6. Klyaritskaya I. L., Moshko Yu. A. Prokinetics and modern approaches to the treatment of GERD. The Crimean Therapeutic Journal. 2011. No. 2: 45-49.

7. State register of medicines and medical devices registered in the Republic of Uzbekistan. 2016-2020.

8. S.E. Ravshanova, Kh.M. Yunusova Analysis of assortment positions of the local pharmaceutical market of non-narcotic analgesics. Materials scientific and practical conference with international participation "Creation of competitive medicines - a priority direction of development of pharmaceutical science". - 2018. No. 22: 201-203.

9. S.E. Ravshanova, Z.Kh. Zufarova Study of the local market for non-narcotic analgesic drugs. Materials of the republican, scientific and practical conference (with international participation) "Pharmacy: science, education, innovation and production". - 2017: 121122.
10. Klyaritskaya I. L., Viltsanyuk I. A., Chernukha S. N. Experience of motorix monotherapy in patients with postprandial distress syndrome. The Crimean Therapeutic Journal. 2008. No. 2: 54-58.

11. Grinevich V. B., Sablin O. A. Prokinetics in clinical practice. M: Medicine. 1998; 5-7.

12. S.E. Ravshanova, Kh.M. Yunusova Marketing analysis of range non-narcotic analgesics in Uzbekistan. Pharmacy, scientific and practical journal. - 2016: 828-831.

13. S.E. Ravshanova, Kh.M. Yunusova, Sh.Z. Ziyaev, Z.Kh. Zufarova Assessment of the conjunction of capsulated medicinal preparations of the pharmaceutical market of the Republic of Uzbekistan. Science of the XXI century: problems and prospects. .-2015. No. 1: 77-80.

14. Chernyavsky V.V. Possibilities of modern prokinetics in the correction of the motility of the digestive tract. Internal medicine. - 2008. No. 1(7): 42-45.

15. Ravshanova S E, Yunusova Kh M. Research research research tablet dissolution "Analfenon". Journal "Internauka". 2019; 11 (93):29-31.

16. Ravshanova S E, Yunusova Kh M. Some features of selection of composition and technology of tablets "Anafenon". Medical science of the XXI century looking towards the future. Materials of the international scientific-practical conference (67th annual), dedicated to the 80th anniversary of TSMU named after Abuali ibni Sino and "Years of development of the village, tourism and folk crafts.2019;3:48-49.

17. Ravshanova SE and Yunusova KhM. Effect of various binding agents on the quality of hard gelatin capsules "Analfenon". International Journal of All Research Writings. 2020; 1(10): 81-85. 